看護ケアの質の評価基準に関する研究

一看護ヶアの過程評価尺度の開発一

○山本あい子、片田範子、上泉和子、篠崎和子 (兵庫県立看護大学)

大崎富士代 (兵庫県立看護大学大学院

看護学研究科修士課程)

中込さと子（聖路加看護大学大学院看護 学研究科博士前期課程)

1.はじめに：看護ヶアの質の評価は、看護の本質の追究と看護の質の向上の為に 必要かつ重要なことである。当研究班では、過去 4 年間にわたり看護ヶアの質の評 価基準の作成に着手してきている。今までの研究活動では、質の高い看護ケアを構 成する 9 要素を抽出し、それらの要素を構成する看護技術を明確にした。更にこれ らの看護技術を評価するための看護ケア過程指標を導きだし、また作成した過程指 標の臨床場面での使用可能性を検討した。この結果、使用尺度の精錬の必要性や評 価尺度もしくは評価基準の作成の必要性などが示唆された。そこでこれらの結果に 基づき、看護過程指標を特定し、更に評価尺度を開発したのでここに報告する。

2. 研究目標：1）看護ケアの質を保持/改善するために必要な過程指標を特定す る。2)良い看護ケアを提供するために、どのような改善が必要かが明瞭となる看 護ケア過程の評価尺度を開発する。

3. 研究方法：本調査は質的研究法を用いている。データ収集には、(1)半統制型質 問紙を用いた面接法、(2)処置場面の参加観察法、更に(3)看護記録に残されている記 述分析のための書類調査を用いた。また得られたデータの分析には、専門家を交え ての内容分析を実施した。調査場所は、質の高い看護を提供していると言われてい る病院 7 施設、8病棟であり母性・小児・精神科の各病棟は今回の調査からは除外 した。調査対象者は、次に述べる条件を備えた患者のプライマリーナース、もしく は該当患者のその日の受け持ち看護婦、あるいは該当患者を最も良く知っている看 護婦とした。患者選択の条件は、(1)その病棟での入院日数が 1 週間以上である、(2) 疼痛があり鎮痛剂を使用している、(3)保清の介助が行われている、そして (4)調査日 に処置、あるいは検査があるの 4 点であった。

\title{
4. 結果および考察
}

\section{1) 看護ヶア過程指標の特定}

データ分析の結果、看護婦が行うケアの目的によって 6 項目（２６細項目を含む） の看護過程指標を特定した。それぞれの過程指標とは、(1)患者への接近：「看護婦 が患者や家族に近づき、関係を作りながら患者や家族の状態を把握していくこと」、 (2)患者あるいは家族の内なる力を強める：「患者や家族に見通しや予測性を持たせ ることにより、内なる力を強める看護婦の行為」、(3)家族の紏を強める：「家族員 間の料を強めるという意図性を持って、家族と一緒に看護婦がケアを行っているこ 
と」、(4)直接ヶア：「適切な判断や他職種との連携を通して、看護婦は患者の個別 性に合った看護ヶア（特に保清と痛みへの介入）を提供している」、(5)場を作る：

「看護婦がチームの連携がうまくいくように働きかけていること」、(6)インシデン 卜を防ぐ：「患者の回復状態や希望に添いながら、危険性を考慮しつつ看護ヶアを 積極的に進めていくこと」である。

\section{2) 各過程指標の評価尺度の開発}

データ分析の結果は、看護婦が行うケアには様々な段階があることを示している。 各過程指標毎のケアの段階と、それに基づき作成した評価尺度を以下に述べる。 （1）患者への接近：患者や家族に関する看護婦の把握は、「知っている」か「知 らない」かに分類できた。更に「知っている」ことの程度は、その根拠別にく確認 済み $><$ 推測 $><$ 憶測 $>$ の 段階が確認できた。看護婦が患者により接近している 場合は直接的根拠に基づき状況を把握しているので、〈確認済み>を 3 点として、 以下 2 点、1点と得点に段階をつけた。また患者の把握内容にもレベルがあり、医 学的側面、患者の生活状況、看護ヶアが含まれていれば、各 1 点、計 3 点とした。 (2) 患者あるいは家族の内なる力を強める: デー夕分析の結果、回答は 4 段階に 分類できた。く1日の予定等の情報を患者に伝え、かつ実施時間や方法等を患者と 協議して決めている><時間や実施者の予定を伝えている $>$ く何が予定されている かを伝えている>であり、これらを順次 3、2、1点とした。く何も伝えていない >場合は 0 点とした。（3）家族の絆を強める：く家族の䋖を強める意図がケアの 中にあるもの>と<家族と共にヶアをするために何かエ夫をしているもの>が見ら れ、これらを各 1 点とした。（4) 直接ヶア：〈患者の状況に合わせてケアを行っ ている>くケアの妥当性を検討している>をそれぞれ 1 点とした。痛みへの介入に は、く患者の生活等を含めて痛みのコントロールを述べている><個別性が見えな い><回答できず>があり、順次 2、1、0 点とした。また痛みへの介入の効果判 定については、く根拠を含めて述べている>く効果判定をしているが根拠が不明瞭 $><$ 判定をしていない>の段階があり、これも順次 2、1、0 点とした。（5)場 をつくる：看護婦同士が協同しているかどうかに段階が認められる。<自主的に手 伝う><仲間から頼まれて手伝う ><手伝っていない>であり、それぞれを2、1、 0 点とした。また突発的な状況下で看護婦がく自分の役割を認識している $>$ と 1 点、 更に<流動的なその場の状況を把握している>2 点、<固定的な状況を把握してい る>で 1 点とした。（6）インシデントを防ぐ：看護婦がく患者のリスクを判断し ている ><看護行為が目指しているものや患者の希望を理解している インを理解している>で各 1 点、更に手順通りにヶアをしていなかったり、勝手に 手順を修正した場合には、ー1点とした。この評価尺度を用いて看護婦の行うケア の得点化を試みると、各医療施設毎に、かつ各指標毎に得点差が生じていた。作成 した評価尺度は、どのような看護ケアの行為の違いが、看護ケアの質に結びついて いるかを明瞭に示している。

*当研究は、平成 8 年度厚生省看護対策総合研究事業(班長片田範子)の一部である。 